\title{
Kırsal Yerel Halkın Turizmden Ekonomik Olarak Yararlanma Durumu: Salda Gölü Örneği
}

\author{
The Economic Benefit to Local Rural People from tourism: \\ The Case of Salda Lake
}

\section{Serdar CEYLAN* İhsan BULUT ${ }^{* *}$}

\begin{abstract}
$\ddot{O}_{z:}$ Araştırmanın amacı, kırsal bölgelerde gelişen turizmin yerel halkın ekonomik kalkınmasında nasıl bir rol oynadığını anlamak; ayrıca kırsal turizmin alandaki gelişimine karşın yerel halkın tutumunun nasıl olduğunu anlamaya çalışmaktır. Araştırma nitel araştırma deseninde yürütülmüşs, görüşme ve gözlem teknikleri çalışmada kullanılmıştır. Yarı yapılandırılmış görüşme formları üzerinden yerel halk ile yüz yüze görüşmeler gerçekleştirilmiş; elde edilen veriler betimsel olarak analiz edilmiştir. Araştırma bulgularına göre, göl alanı son üç yıldır turizmde popüler olmuş ve yılda 700 bin ziyaretçiyi kendisine çekmiştir. Köy halkından yaklaşık 30 kişi, göl kenarında yöresel ürünler satmaktadır. Ayrıca yerel halk, Salda Köyü içerisine pansiyonlar inşa ederek turizmden yararlanmaya çalışmaktadır. Göl çevresinde Kaymakamlık tarafından inşa edilen kafe ve büfe işletmelerinde Salda Köyü kadınları sezonluk olarak istihdam edilmektedir. Göl çevresinin temizliğinde İSKKUR üzerinden 10 köy kadının da istihdam edildiği görülmektedir. Ancak alanının 2019'da Özel Çevre Koruma Bölgesi ilan edilmesiyle yerel halkın çadır ve konteynırlarda yiyecek ve içecek satması yerel yönetimlerce yasaklanmıştır. Yerel halk, yerel yönetimlerin alandaki sıkı kontrollerini ve yasaklamalarını eleştirmektedir. Sonuç olarak; kırsal kalkınmanın gerçekleştirilebilmesi ve kırsal yoksulluğun azaltılması için, yerel halkın turizmin içerisine dâhil edilmesi ve yapılacak Salda Gölü Millet Bahçesi'nden yerel halka işletme yerlerinin verilmesi sağlanmalıdır.
\end{abstract}

Anahtar Sözcükler: Kırsal Turizm, Turistik Ürün, Yerel Ekonomik Gelişme, Salda Gölü, Burdur

\begin{abstract}
The purpose of this study is to understand what role tourism plays in the economic development of local regions. Moreover, to determine the attitude of people towards tourism. The research was conducted through observation and the interview techniques of the qualitative method. Interviews face-toface with stakeholders were made with semi-structured interview forms in 2019. The obtained data were analysed descriptively. According to the findings of this research, Salda Lake, Burdur, has been popular in tourism for the last three years and it has attacted 700 thousand visitors annually. About 30 villagers sell their local products by the lake. Moreover, local people have ran hostels in villages. The Governorship run café and buffet by the lake, and it employs village women in these businesses. Also it employed about 10 the women in lake area as cleaning workers. Because the study area was made a Protection Region, touristic product selling by the local people was banned by the governorship. Moreover, the villagers criticize the strict checking by public institutions in the area, because of it being a protected area. As a result of this study, it is indicated that local people should be inside tourism, for rural development and to diminish rural poverty. The business which will made inside nation garden, should give to villager.
\end{abstract}

Keywords: Rural Tourism, Touristic Product, Local Economic Development, Salda Lake, Burdur

* Arş. Gör. Dr., Mehmet Akif Ersoy Üniversitesi, Fen Edebiyat Fakültesi, Coğrafya Bölümü, Burdur. serdar_ceylan_51@hotmail.com, https://orcid.org/0000-0002-9599-5586

** Prof. Dr., Akdeniz Üniversitesi, Edebiyat Fakültesi, Coğrafya Bölümü, Antalya. ihsanbulut@akdeniz.edu.tr, https://orcid.org/0000-0003-4520-4421 


\section{Giriş}

Kırsal alanlar, Robert \& Hall (2001) ve Chuang'a (2010) göre, dünyanın pek çok yerinde turizm faaliyetleri için gerekli ortamı sağlamış ve günümüzde kırsal turizm, çok önemli ve hızla büyüyen bir endüstri haline gelmiştir. Perdue el al. (1987) ve Chuang'a (2010) göre, dünya turizminin gelişimi ile ilgili son zamanlarda yapılan bilimsel çalışmaların büyük bir kısmı da turizmin ev sahibi toplum üzerindeki etkilerine odaklanmıştır. Çünkü turizm ve turizme bağlı gelişim gibi pek çok farklı değişken, dünya çapında nüfusu etkilemeye başlamıştır. Böylece, yerel halkın turizme karşı tutumları sosyal bir konu haline gelmiştir. Kırsal turizm, dünya genelinde kırsal bölgelerde alternatif gelir kaynağı olarak bilinmekte ve uygulanmaktadır. Kırsal turizmin yapıldığ 1 yöre ve yerleşmelerde bir takım olumlu ve olumsuz etkiler de görülebilmektedir. Altunel'e $(2009,2)$ göre, turizmin bu etkilerinden en çok etkilenen paydaşlardan bir tanesi de turizmin gerçekleştiği alanda yaşayan yöre halkı olmaktadır. Jurowski et al. $(1997,3)$ ve Yoon et al. (2001, 363) göre, turizmin sürdürülebilir olması için yöre halkının desteğini kazanmak önemlidir. Turizmin gelişimine destek veren bir toplumun elde edilebilmesi için yerel halkın turizmin gelişimine yönelik tepkilerini ve bu tepkileri etkileyebilecek faktörleri anlamak çok önemlidir (Göktaş-Kulualp \& Sarı 2019, 644-45). Turizmin bir alandaki gelişimini açıklayan Butler'ın (1980) teorisi ve modeli dışında, turizm araştırmalarında yerel halkın turizmin gelişimine yönelik davranışlarının açıklanması için sosyal değişim teorisi (SDT) de kullanılmaktadır (Ekici \& Çizel 2014, 74). Turizm literatüründe pek çok çalışma (Perdue et al. 1987; Ap 1992; Getz 1994; Lindberg \& Johnson, 1997; Jurowski et al. 1997; Yoon et al. 2001; Teye et al. 2002), yerel halkın alg1, tutum ve tepkisini ölçmek için SDT'yi kullandığı görülmektedir (Altunel 2009, 51; Ekici \& Çizel 2014, 75).

Harrill (2004, 5-12) ve Lee'ye $(2013,2)$ göre, SDT ile turizmin ilişkisi, "faydacılık" ilkesine bağlı olarak sürdürülmektedir. SDT kapsamında bir turizm alanında yaşayan yerel halkın beklentisi ile hissedilen faydalar doğru orantılı olursa, turizmin gelişiminin beklenilen düzeyde olması mümkün olmaktadır. Bu nedenle, SDT yerel halkın tutumu ile ilişkili olarak yerel halkın menfaatleri doğrultusunda gelişim göstermektedir. SDT kapsamında turizmin gelişimi üzerine yapılan araştırmalar, turizmin gelişimine yönelik tutumun, yöre halkının bu durumdan sağlayacağ 1 faydaya dayandığı sonucuna varmıştır. Teye et al. $(2002,670)$ göre, SDT yerel halkın tutumlarına uygulandığında, bölgede yaşayanlar fayda elde etmek istedikleri için, turizm çal1şanlarına ve turistlere ayrıcalıklı davranmaktadırlar. Yöre sakinlerinin turizmin oluşturduğu kirlilik, trafik sıkışıklı̆̆ gibi olumsuzluklara anlayış göstererek turizmin gelişimine destek verdikleri ve misafirperver oldukları gözlenmiştir. Perdue et al. (1987, 420-29) Kolorado'da SDT'ye göre yaptıkları çalışmada ise, yerel halkın turizmden duyduğu memnuniyet belirlenmiş ve turizm sezonunda yerel halkın rekreasyonel faaliyetlere daha az katıldığ 1 sonucuna varılmıştır. Sonuç olarak, yerel halkın değişime katılarak turizmin gelişimine destek vermesi için hissedilen faydaların artması veya artma algısının oluşumunun gerçekleşmesi gerekmektedir. Yoon et al. $(2001,364)$ göre, SDT'yi benzer şekilde açıklamaktadır. Eğer yerel halk makul bedeller ödeyerek değişimden fayda sağlayacağına inanırsa değişim ilişkisine girmektedir. Diğer bir deyişle, turizmin olumlu etkilerinin olumsuz etkilerini aşacağı algılanırsa, yerel halk turizmin gelişmesi için destek vermektedir (Altunel 2009, 51; Ekici \& Çizel 2014, 74; GöktaşKulualp \& Sar1 2019, 644-45). Ekici \& Çizel'in $(2014,84)$ SDT’ye göre iki farlı turizm alanında yaptıkları çalışmada, her iki bölge halkının turizm gelişiminden fayda sağladıkça turizmin pozitif etkileri konusunda algı seviyelerinin arttı̆̆ görülmüştür. Bu nedenle, SDT'nin "faydacılık" ilkesi ile ilişkili olarak, yerel halkın turizmin ekonomik olarak yararlanma durumuna bakmakta yarar vardır. Bu bağlamda araştırmanın amacı, kırsal bölgelerde gelişen turizmin yerel halkın ekonomik kalkınmasında nasıl bir rol oynadığını Salda Gölü araştırma sahası üzerinden anlamak; ayrıca kırsal turizm alanındaki yerel yönetim uygulamalarına ve 
turizmin alandaki gelişimine karşın yerel halkın tutumunun nasıl olduğunu anlamaya çalışmaktır. Kırsal alanlarda gerçekleşen kırsal turizm faaliyetinin yerel halkın refahının artmasında ya da kalıcı yoksulluğun devam etmesinde nasıl bir etkide bulunduğunun anlaşılması bakımından bu araştırma önem arz etmektedir.

\section{Literatür}

Vaugeois (2000) ile Richardson (2010), yeni yerel ekonomik aktivitelerin oluşturulmasında turizmi, bölgesel bir kalkınma aracı olarak görmektedir. BM Dünya Turizm Örgütü (2002) ve Vaugeois'e (2000) göre, gelişmekte olan ülkeler turizmi ekonomik kalkınmayı desteklemede ve yoksulluğu azaltmada önemli bir araç olarak görmektedir. Modeste (1995), Creaco \& Querini (2003) ile Steiner'e (2006) göre turizm, yerel ekonominin çeşitlendirilmesine, bölgesel kalkınmaya, istihdam ve gelirin oluşturulmasına ve yatırımların alana çekilmesine olanak sağlayan ekonomik büyüme için etkili bir sektördür. Nitekim Durbarry'a (2002) göre, gelişmekte olan ülkelerde yapılan araştırmalar, ekonomik büyüme ile turizmin gelişimi arasında pozitif bir ilişkinin var olduğunu tespit etmişlerdir (Meyer \& Meyer 2015, 197-198). Oğuzbalaban (2017, 1321), turizmin geliştiği yörenin yapısı üzerinde etkili olmasının yanında sosyo-kültürel, çevresel, ekonomik ve eğitimsel etkiler bakımından da önemli sonuçlar ortaya koyduğunu; bu sonuçlardan etkilenen topluluğun başında turizmin gerçekleştirildiği yörede yaşayan yerel halkın geldiğini belirtmektedir. BM Dünya Turizm Örgütü’ne (2002) göre, turizmin istihdam oluşturma potansiyeli, yerel ekonomiyle bağlantısı, döviz kazandırması ve çarpan etkisiyle ekonomik büyümeye ve kalkınmaya öncülük edebilecek bir potansiyeli olduğu bilinmektedir. BM Ticaret ve Kalkınma Konferansı (UNCTAD)'a (2010) göre turizm, bir yörenin gelişmesi için önemli sektörlerden birisidir. Turizmin bir yörenin ekonomisine olan katkısı turizmin diğer endüstrilerle olan doğrudan ve dolaylı bağlantıları yoluyla ortaya koyulabilir. Yerel düzeyde turizmin gelirleri ve istihdam olanakları artırıcı ve yoksulluğu azaltıcı etkileri bulunmaktadır. Kırsal turizm, yerel boyutta kırsal alanlarda yaşayan kadınlara istihdam sağlamakta; tarımsal gelirler dışında yerel halka ek gelirler sunmakta; yerel ekonomileri canlandırarak ve göçü yavaşlatarak kırsaldaki sosyo-ekonomik gelişmeyi artırmaktadır. Başka bir deyişle, kırsal kesimde yaşayanların tarımdan elde ettiği gelirin düşük olması, işsizliğin kırsal bölgelerde yüksek olması kırsal turizmi bu alanlarda cazip hale getirmektedir (Torun 2013, 31-33). Kırsal alanlarda turizmin gelişimi ile birlikte fiziksel altyapı sorunu ortadan kalkmakta, yöre insanlarında yerel girişimcilik ruhu gelişmekte, yöresel el sanatları (halı, kilim, el işlemeleri, yiyecek ve içecekler) turistik bir ürün olarak pazarlanarak yerel halka ek bir gelir sağlamaktadır (Çeken et al. 2007, Ün et al. 2012, 349).

Oğuzbalaban'a $(2017,1322)$ göre, turizmin gelişmesinde yerel halkın önemli bir yere sahip olduğunun anlaşılması, birçok yazar tarafından yerel halkın turizme ilişkin tutumuyla ilgili araştırmalar gerçekleştirilmesine neden olmuştur: Látková \& Vogt (2012), Hanafiah et al. (2013), Dimitrios et al. (2014), García et al. (2015). Turizmin ekonomik etkilerini ölçmeye yönelik teorik ve uygulamalı birçok araştırma yapılmıştır. Gökovalı (2010), Dritsakis (2012) ile Othman et al. (2012) turizmin ekonomik büyümeye etkisi olduğunu; Moore \& Craigwell (2008) ile Othman et al. (2012) turizmin yatırımlara etkisi olduğunu; Archer \& Fletcher (1996) ile Aguayo (2011) ise turizmin istihdama etkisi olduğunu; Shan \& Wilson, (2001); Hanafiah \& Harun (2010) ise turizmin ödemeler dengesine etkisi olduğunu ortaya koymuştur (Terzioğlu \& Gökovalı 2017, 29). Eralp (1974), turizmin etkilerinin doğal olarak turizm faaliyetlerinin başlaması ile ortaya çıktığını ortaya koymuş ve bir turizm alanı olan Erdek (Balıkesir) ve turizm dışı bir alan olan Kalecik (Ankara) yerleşmelerini karşılaştırarak turizmin sosyal ve ekonomik etkilerini araştırmıştır. Mathieson \& Wall (1992) çalışmasında, turizm faaliyetlerinin plansız gelişmesi durumunda, çevre üzerinde geri dönüşü çok zor veya imkânsız etkileri olabileceği 
üzerinde durmuştur. Özdemir et al. (2000), turizm sektörünün insanlar üzerinde "arzulanan" değişikliklere yol açtığını ve turizm ile oluşan istihdamın işsizlik sorununa olumlu katkıda bulunduğunu ifade etmişlerdir. Mason \& Cheyne'nin (2000) çalışmasında kırsal turizmin gelişimi açısından, yerel halkın tepkisini araştırmış ve turizmin olumlu ve olumsuz etkileri üzerinde durmuştur (Çalışkan \& Tütüncü 2008, 133). Ayrıca Baykal (2004), yerel turistik ürünlerinin kırsal turizm için önemini araştırmıştır.

\section{Yöntem}

Çalışma, nitel araştırma yönteminde yürütülmüş olup görüşme ve gözlem teknikleri kullanılmıştır. Saha araştırmasından elde edilen görüşme ve gözleme dayalı veriler çalışmanın veri setini oluşturmaktadır. Görüşme yapılan katılımcılar olasılıklı (rastlantısal) olmayan amaçlı örneklem yöntemine göre belirlenmiştir. Amaçlı örneklem yöntemine uygun olarak, katılımcıların araştırma alanı ve araştırma konusu ile ilgili ve bilgili kişiler olmasına dikkat edilmiştir. $\mathrm{Bu}$ nedenle, belediye başkanı, muhtar, yerel işletmeciler ve turistik ürün satan yerel halktan kişiler görüşme yapmak için seçilmiştir. Görüşülen kişi sayısının evreni temsil edip etmediğine bakılmaksızın, görüşmeler veri doygunluğu ve veri çeşitliliği sağlandığında sonlandırılmıştır. Görüşmeler, yarı yapılandırılmış görüşme formları üzerinden, yüz yüze gerçekleştirilmiştir. Görüşme sorularının tam olarak yapılandırılmasından kaçınılmış; görüşme soruları üzerinden katılımcı ile derinlemesine görüşmenin yapılması hedeflenmiş; görüşme esnasında konunun açılması için yer yer sondaj sorular sorulmuştur. Görüşmeler ortalama 25-40 dakika arasında sürmüştür. Görüşme soruları; alanın korunması ve millet bahçesi projesi, turizmin alandaki gelişimi ve yerel halkın ekonomik olarak turizmden yararlanma durumu üzerine hazırlanmıştır. Saha gözlemleri, 2019 Temmuz-A ğustos döneminde gerçekleştirilmiştir. Gözlemler ile göl kenarındaki plajlardaki turist yoğunluğu, yerel halk ile ziyaretçilerin etkileşim durumu ve ziyaretçilerin mekânı kullanım deneyimleri belirlenmeye çalışılmıştır.

Araştırma bulgularının bütüncül olarak tutarlı, anlamlı ve güvenilir olması ve etik ilkelerin gözetilmesi çalışmanın güvenirliğini artırmaktadır. İkincil veriler, gözlem ve görüşme teknikleri ile veri çeşitlendirmesinin sağlanması, amaçlı örneklem ile doğru kişilere ulaşılması, sahadaki farklı kişilerle görüşmelerin gerçekleştirilmesi çalışmanın geçerliliğini yükseltmektedir. Başka bir ifadeyle, görüş̧me bulguları okuyucunun anlamlandırabileceği detayda alıntılanarak sunulması ve kendi içinde mantıksal ve anlamsal bir bütünlük göstermesi araştırmanın güvenirliğini artırmaktadır. Görüşmelerde etik ilkelere uyulmuş, kişilere yönlendirici sorular sormaktan kaç1nılmıştır. Ayrıca konuşmaların ses kaydına alınmasında kendilerinden izin alınmış, ses kaydını kabul etmeyen katılımcıların görüşme verilerinde not alma yöntemi izlenmiştir. Yerel turistik ürün satan yerel halkın izni doğrultusunda fotoğraflarının çekilmesi, saha verilerinin analiz ve yorumlanmasında objektif olunması çalışmada gösterilen diğer etik ilkelerdir.

Nitel yönteme dayalı olarak elde edilen ampirik veriler, alıntılama ve kodlamalar şeklinde analiz edilmiştir. Ses kaydına alınan görüşmeler, daha sonra Microsoft Word programına yazılmıştır. Microsoft Word'a yazılan ses görüşmeleri, MAXQDA 12 programına aktarılmıştır. Programın sol ara yüzünde oluşturulan kategoriler altına, sağ ara yüzdeki görüşme metninden alıntılama ve kodlamalar yapılmıştır. Nitel bulgularda daha önceden oluşturulan alt temalar içerisindeki alıntılamalar içerisinden birbiriyle ilişkili kodlar bir araya getirilerek açık kodlama yapılmıştır (Tablo 2-5). Açık kodlamada sabit kodlar ortaya koyulmuştur. Bu kodlar, olayı anlatan betimleyici kodlardır. Aksiyel kodlamada, açık kodlamada oluşturulan sabit kodlar bir araya getirilerek çekirdek kategoriler oluşturulmuş ve veriler arasında yeniden bir bağlantı kurulmuştur. Bu kodlar ile bir olayın ortaya çıkmasındaki nedensel koşullar belirlenmiştir. Seçici kodlamada ise, temel (merkezi) kategori belirlenmiş, diğer kategorilerin merkezi kategori ile ilişkili olarak ortaya çıktığı ifade edilmiştir. Yapılan bu kategorisel analizler (kategorileştirme 
ve kodlamalar) neticesinde, kırsal turizmin etkileri ana kategori içinde soyutlama düzeyinde anlaşılmaya çalışılmıştır.

Çalışma, dört araştırma sorusu üzerinde yoğunlaşmaktadır:

- Yerel halk kırsal turizm faaliyetlerinden ekonomik olarak nasıl fayda sağlamaktadır?

- Göl çevresindeki turizm faaliyeti yoksulluğun azaltılmasında ve kırsal ekonomik gelişmede nasıl bir role sahiptir?

- Yerel halkın alandaki turizmin gelişimine karşı tutumu nasıldır?

- Salda Gölü’nün Özel Çevre Koruma Bölgesi olması ve alana yapılacak olan Millet Bahçesi, göl çevresindeki yerleşmelerde yaşayan yerel halkın turizme katılımını ve turizmden ekonomik olarak yararlanma durumunu nasıl etkileyecektir?

\section{Araştırma Alanı}

Araştırma alanı olan Salda Gölü, Akdeniz Bölgesi'nin kuzeybatısında yer almaktadır. Alan idari olarak, Burdur iline bağlı Yeşilova ilçesinin idari sınırları içerisinde kalmaktadır. Salda Gölü çevresinde Kayadibi, Salda ve Doğanbaba köy yerleşim alanları bulunmaktadır (Fig. 1). Salda Gölü ve çevresi $\left(47 \mathrm{~km}^{2}\right), 1989-1992$ yıllarında "doğal sit alanı" olarak tescil edilerek koruma altına alınmıştır. Araştırma alanının bir kısmı 2011 yılında Tabiat Parkı (120 dekar) ilan edilmiştir. Salda Gölü, 2006 yılında Bakanlar Kurulu kararı ile "turizm merkezi” ilan edilmiştir; ancak 2019 yılı 824 Sayılı Cumhurbaşkanı Kararı ile "Özel Çevre Koruma Bölgesi" (ÖÇK Bölgesi) olarak tespit ve ilan edildikten sonra gölün "turizm merkezi” statüsü kaldırılmıştır.

Salda Gölü’nde turizm ve rekreasyonel amaçlı üç plaj alanı bulunmaktadır: Beyaz Adalar Plajı (Salda Köyü), Doğanbaba Plajı (Doğanbaba Köyü) ve Belediye Halk Plaj1 (Kayadibi Köyü). “Türkiye'nin Maldivleri” olarak nitelendirilen Salda Gölü, bu özelliğini Salda Köyü giriş kısmında yer alan beyaz kum renginden ve göl kıyısında görülen sudaki renk farklılıklarından almaktadır (Fig. 2). Alanın günümüz turizminde turistik bir ürün olarak pazarlamasında ve markalaşmasında “Türkiye'nin Maldivleri” etiketi öne çıkmaktadır. Nitekim gölün bu doğal çekiciliğini alana gelen ziyaretçi sayılarından anlayabilmek mümkündür. Burdur İl Kültür ve Turizm Müdürlüğü (2019) verilerine göre, Salda Gölü'ne 2018 yılında 689.730 ziyaretçi gelmiştir. 2019 yılının ilk altı ayında ise 398.439 ziyaretçinin göl alanını turizm ve rekreasyonel amaçlı olarak kullanmıştır.

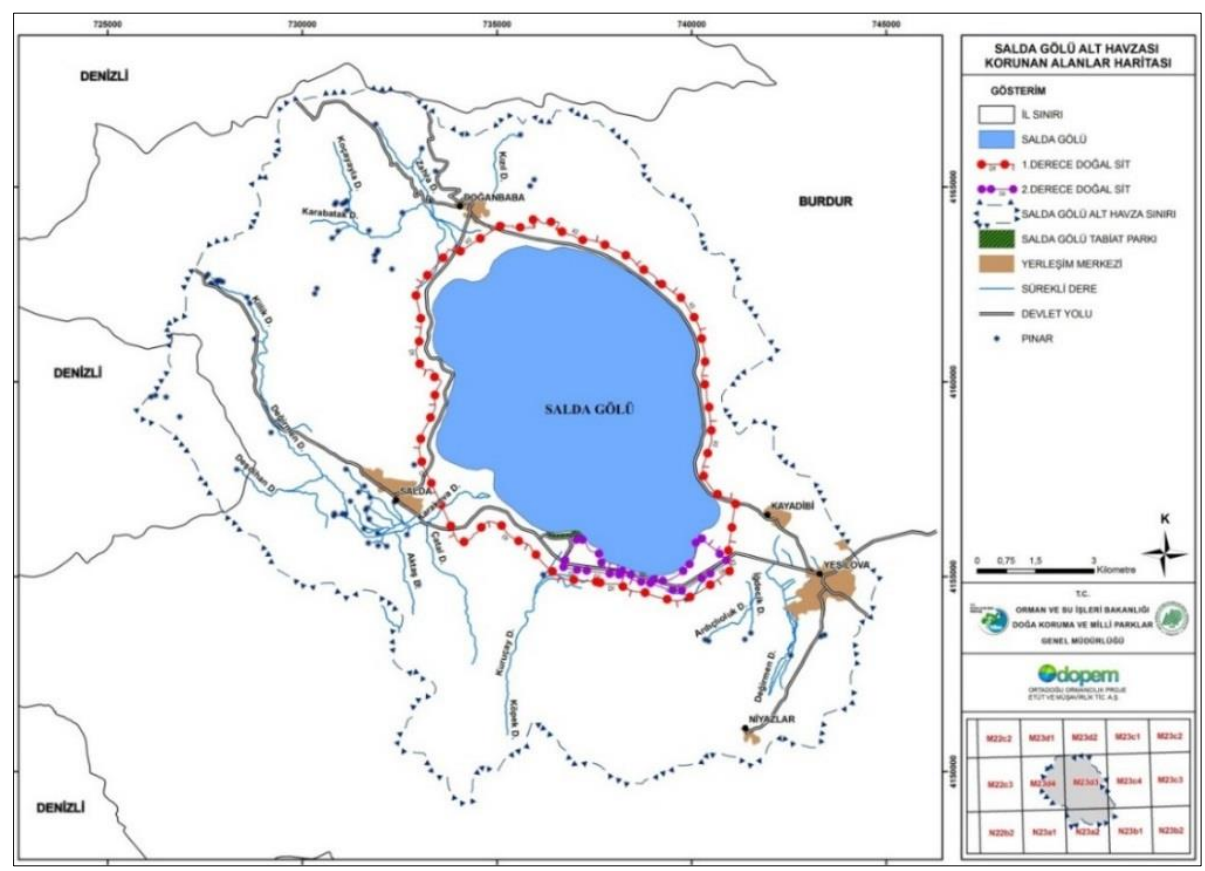

Fig. 1. Salda Gölü Korunan Alan Haritası (Orman ve Su İşleri Bakanlığı, 2013) 


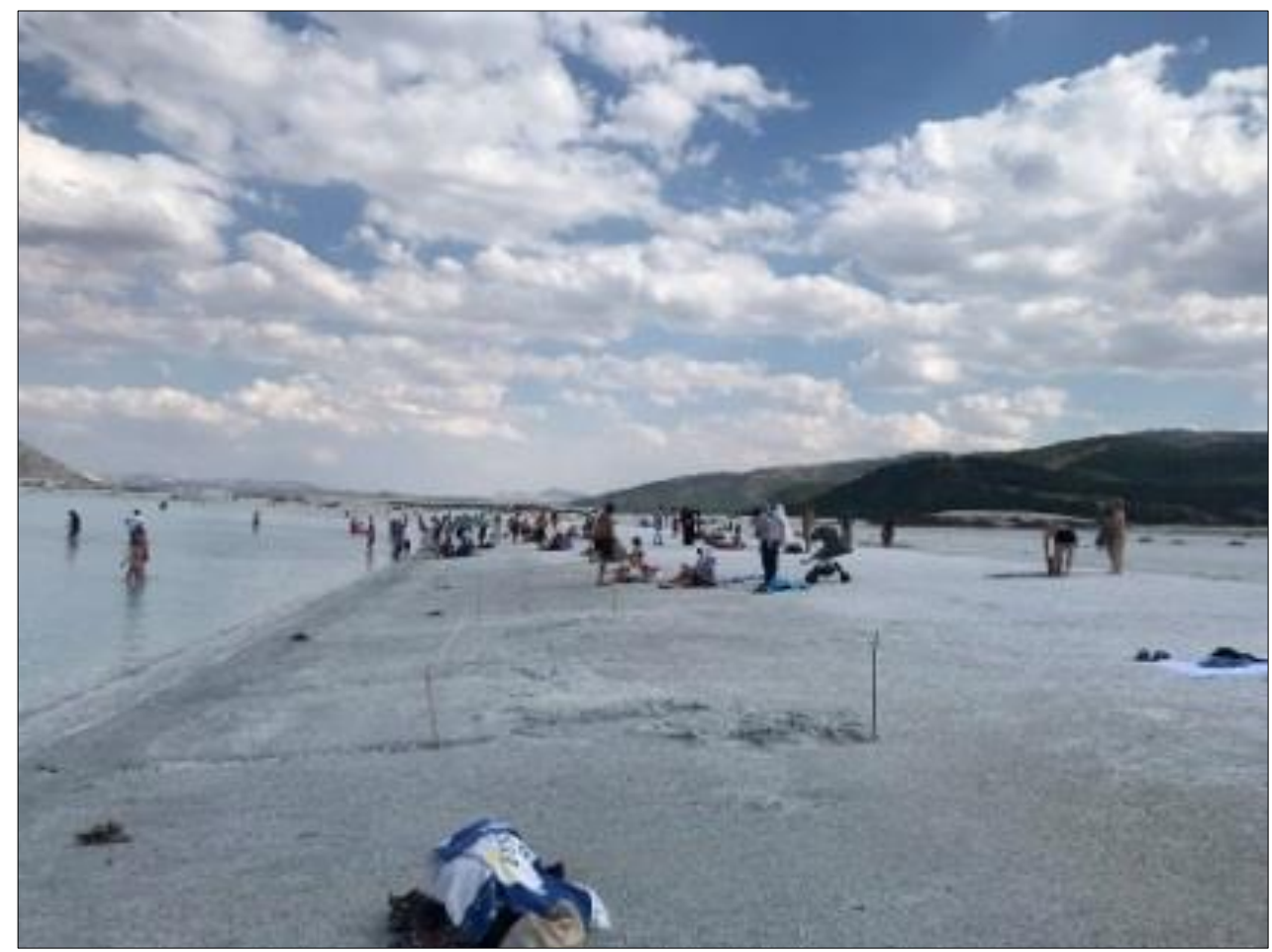

Fig. 2. Salda Gölüne gelen ziyaretçilerden bir görsel (Kaynak: Burdur Yeşilova)

\section{Analiz ve Bulguların Yorumlanması}

Araştırma alanında 7 erkek ve 5 kadın toplam 12 kişi ile görüşme yapılmış, bu katılımcılara ilişkin temel demografik bilgiler Tablo 1'de sunulmuştur.

Tablo 1. Görüşmeye Katılan Katılımcılara İlişkin Bilgiler

\begin{tabular}{llll}
\hline Kod & Cinsiyet & İşi & Açıklama \\
\hline K1 & Kadın & Pazar Esnafı & Salda Köyü yerel halkı, göl kenarında yöresel ürün satıcısı \\
\hline K2 & Kadın & Pazar Esnafı & Salda Köyü yerel halkı, göl kenarında yöresel ürün satıcısı \\
\hline K4 & Kadın & Pazar Esnafı & Salda Köyü yerel halkı, göl kenarında yöresel ürün satıcısı \\
\hline K5 & Erkek & Pazar Esnafı & Salda Köyü yerel halkı, göl kenarında yöresel ürün satıcısı \\
\hline K6 & Kadın & İŞKUR çalışanı & Salda Köyü yerel halkı, Kaymakamlık işletmelerinde çalışan \\
\hline K7 & Kadın & İŞKUR çalışanı & Salda Köyü yerel halkı, göl çevre temizliğinde çalışan \\
\hline K8 & Erkek & Muhtar & Kayadibi Köyü muhtarı \\
\hline K9 & Erkek & Esnaf & Kayadibi Köyü yerel halkı, Belediye Halk Plajı'nda işletmeci \\
\hline K10 & Erkek & Muhtar & Salda Köyü muhtarı \\
\hline K11 & Erkek & Emekli & Salda Köyü yerel halkı (köy ihtiyar heyeti) \\
\hline K12 & Erkek & Kamu Yöneticisi & Yeşilova İlçe Belediyesi Başkanı \\
\hline
\end{tabular}

Görüşme yapılan katılımcıların Salda Gölü ile ilgili görüşleri 5 kategorik başlık altında analiz edilerek temalaştırılmıştır

\section{Kategori 1: Yöresel Turistik Ürün Satan Yerel Halk}

Yapılan görüşmelerde yerel halkın alanın turizmdeki gelişimini önemsediği, turizme katılma ve turizmden ekonomik olarak yararlanmada istekli oldukları görülmektedir (Fig. 3, 4). Burdur Valiliği’nin Salda Gölü'nün gerisinde oluşturduğu pazar satış alanında Salda Köyü yerel halkı 
ev yapımı yiyecekler, el işleri, hasat edilen tarımsal ürünler sattığı belirlenmiştir (Fig. 5, 6).

Abam köy ürünlerini satıyoruz. Cevizimiz, fasulyemiz, iğdemiz, nar ekşimiz, erik sirkesi, havuç sirkesi, badem, ceviz, incir. Bak bir yanda sarımsă̆ımız var. Mısırımız, nohutumuz, eriğimiz var. Yok yok yani, hepsi var. Hep köy ürünü bunlar. Daha salçalarımız var, elle örülmüss şeylerimiz var. Ceviz ezmelerimiz, incirlerimiz var. Ithal hiçbir şeyimiz yok, hep yerli. ...Marmelat da sattyorum, dolu, 50-100 kadar var evimde. Kirazım, vişnem, kayısı kompostolarım dolu evde. Reçellerim var, incir reçelim var, erik reçelim var. ...Ü̧̧ senedir buradayız. Kaymakamlık Valilik açtı burayı (pazar satıs yerini). Memnunuz (buradan). Allah da razı olsun onlardan... (K1).

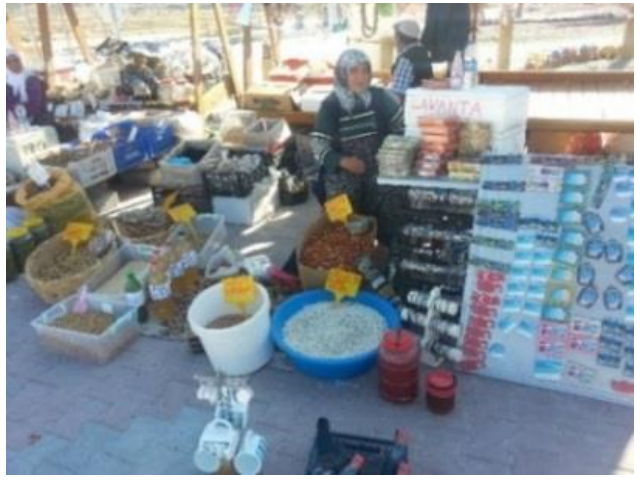

Fig. 3. Yöresel ürün satan kadınlar

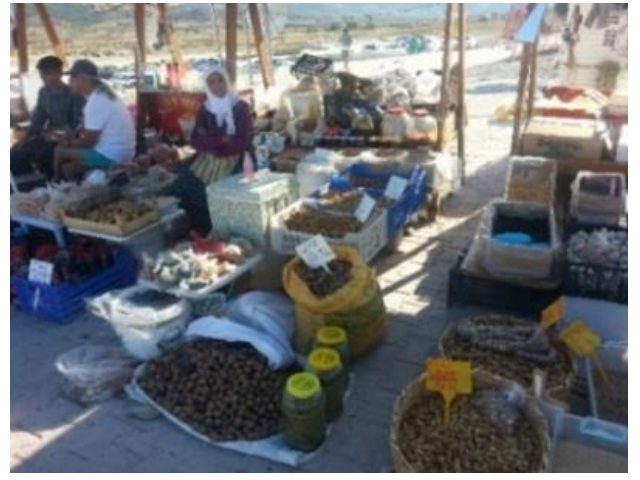

Fig. 4. Yöresel ürün satan yerel halk

Salda Köyü'nden göl kenarında oluşturulan pazar alanına gelen yaklaşık 25 kişinin olduğu, ancak pazar alanının dar olması nedeniyle hafta sonlarında kendi ürününü satacak yer bulamayan kişilerin olduğu belirlenmiştir:

...Biz burada yan yanayı. Dip dibe böyle insanlar. Siğmiyor. Ön taraflara koymasak ürünümüzü tezgâh almıyor. Orda kavgalar da oluyor, tartışmalar da oluyor. Bir karış yer için adam tartı̧̧ıor. Çünkü yer yok, alan dar. Köyden gelecek olan pazarcı daha çok. Hafta sonları buraya o kadar pazarcı geliyor ki sıkış sıkış ya insanlar. Pazar yerinin büyümesi lazım en başta. ...Köyden gelen talep çok, gelmek isteyen köylü çok. 26 tane pazarcl esnaf var şu an burada. Hafta sonu burada 35 kişi olur en az. Siğmiyor (K2).

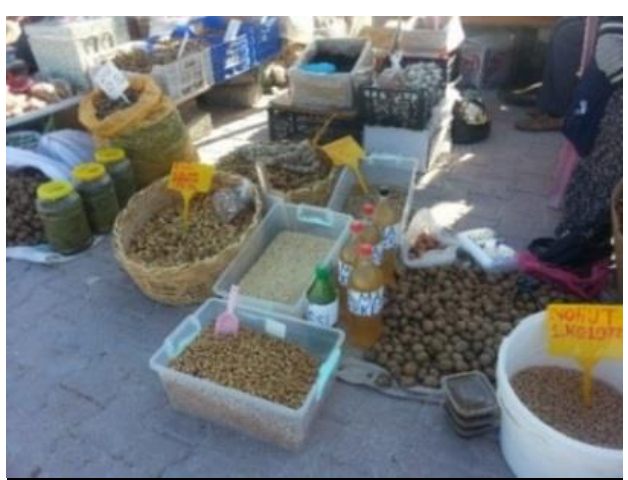

Fig. 5. Satılan yöresel turistik ürünler

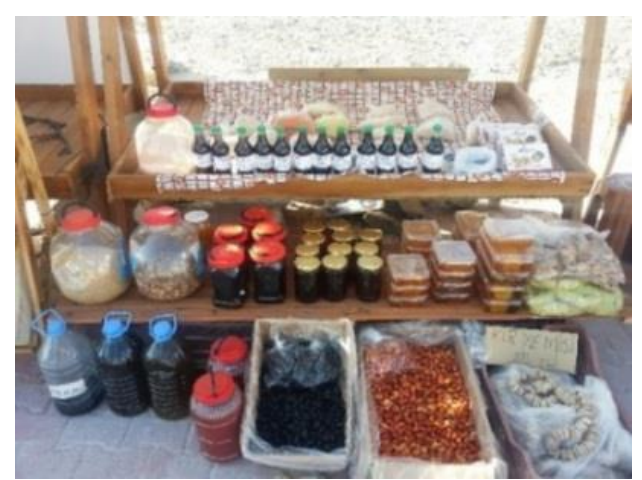

Fig. 6. Satılan yöresel turistik ürünler 
Salda Gölü'ne gelen ziyaretçilere yapılan satışlardan dolayı, yöre halkının turizme karşı tutumunun olumlu olduğu ve sattıkları ürünlerden dolayı ekonomik olarak turizmden bir yarar sağladıkları görülmektedir:

Satışlar iyi Allah bereket versin. 3-5 oluyor yine (K3)....Ama gelen insanlardan memnunuz, çünkü 3-5 kuruş sebepleniyoruz. Yani isteriz ki sürekli olsun, devaml olsun. Biz elimizden geldiğince gelen misafirler e ilgi alaka gösteriyoruz, memnun etmeye çalışlyoruz (K2). Gelenlerin alım gücü maşallah güzel. Ço güzel ya. Ben hafta içi olduğu için güzel yaptım alışverişimi. Ankara, İstanbul, Konya gibi uzaktan gelenler yeyip alıp gidiyor yani. Bak nar ekşilerim falan hiç kalmadl, sabahtan beri bitti (K1). Bahçemiz var, lavanta bahçemiz Yeşilova'da. Onun ürünlerini yaplveriyoruz. Lavanta kolonyasl, lavanta yağı, sabunu, ceviz ezmesi Burdur'un. İki senedir yapıyorum salda köyündenim. Satış oluyor Allah

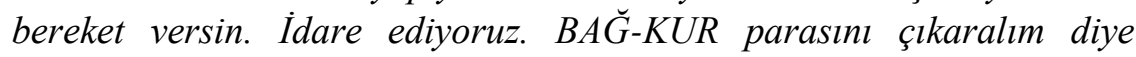
çalışıyoruz (K4).

Salda Köyü muhtarlığının köy ürünleri sertifikalama ve coğrafi işaretini almak için, bir girişim başlattığı da görülmektedir. Bu durum, turizme girme konusunda yerel halkın istekliliğini göstermektedir (Tablo 2).

...Kooperatif olarak, onun için, gerekli yerlere müracaat ettik. Alabilirsek kooperatif olarak poşetleyeceğiz. Ambalaj üzerine yazacağız "Salda Tarımsal Kalkınma Kooperatifi". Herkese standart. En azından poşetleri vatandaşlara (köylüye) dağıtacă̆ız, standart ürün üretilmesi için. Bunlar (köylü), onun adı altında satacaklar (K10).

Yerel yönetimler, alanda satış yapan yerel halkın yöresel ürünler satmalarını istemekte; dışardan turistik ürünlerin (şort, şapka, fötr, terlik vb.) getirilip satılmasına sıcak bakmadığı ifade edilmektedir. Bu durum, yerel halkın tepkisine neden olmaktadır.

Kaymakamlık daha sıktı bizi burada. Mesela "bunları (deniz şortu, şapka) satmayacaksiniz, böyle şeyler getirmeyeceksiniz” (diyor). Ne satacağız tarhana bulgur. Tarhana bulgur da benim buradaki masrafimı çıkarmıyor ki. "Dışardan bir şey getirme, kendi ürününü sat" diyorlar. Sikıntıyı soktu yani bize. ...Bak bu arkadaşın aynı ürün, bu arkadaşın aynı ürün. Bunun ayrı ürünü olsa, ben foter satsam, bu başka şey satsa buraya daha fazla satış girmez mi köyümüze? Çeşit çeşit böyle konsa, satılsa daha iyi olma mi? (K1).

Bakın ben şapka ve şort satıyorum sezon başında. Vali bey bize dedi ki "şort, havlu satmayacaksiniz". Neden dedik, ne zararl var. Yok, sadece tarhana, bulgur satacaksiniz. ... Satmayacaksiniz dedi. ...Kaymakam bey bize yasak getirdi sezon boyunca, şimdi sezon bittiği için uğraşmıyorlar (satmamıza) (K3).

\section{Kategori 2: Kaymakamlığa Bağıı İşletmelerde Çalışan Kadınlar}

Araştırma alanı çevresinde yaşayan insanlar, göle gelen ziyaretçilerden memnun oldukları; ancak ÖÇK bölgesinin oluşturulması nedeniyle alandaki denetimlerin artması ve turistik özel işletmelere izin verilmemesi nedeniyle yerel yönetimlere karşı bir tepki gösterdikleri ve artan bir eleştiri yaptıkları görülmektedir. 
Tablo 2. Yöresel Satı̧lara ve Yerel Halkın Memnuniyetine İlişkin Tematik Kodlama

\begin{tabular}{|c|c|c|c|}
\hline Kategori & İfade (Açık Kodlama) & Aksiyel Kod & Seçici Kod \\
\hline $\begin{array}{l}\text { Turistik } \\
\text { Ürün } \\
\text { Satışları }\end{array}$ & $\begin{array}{l}\text { Üç senedir buradayız. Memnunuz (buradan) } \\
\text { Köylü Salda'ya gelen ziyaretçilerden memnun } \\
\text { Gelen insanlardan memnunuz, çünkü 3-5 kuruş } \\
\text { sebepleniyoruz } \\
\text { Satışlar iyi Allah bereket versin } \\
\text { Gelen misafirleri memnun etmeye çalışıyoruz } \\
\text { Pazar yerinin büyümesi lazım en başta } \\
\text { Dişardan bir şey getirme, kendi ürününü sat } \\
\text { diyorlar } \\
\text { Köylümüz gözleme satarak bir daire parası } \\
\text { kazandı }\end{array}$ & $\begin{array}{c}\text { Pazar yeri küçük } \\
\text { İthal ürün satışı } \\
\text { yasak } \\
\text { Satışlar iyi } \\
\text { Sebepleniyoruz } \\
\text { Memnunuz }\end{array}$ & $\begin{array}{l}\text { Pazar yerin küçük ve } \\
\text { satılan ürünler aynı } \\
\text { olsa da satışların iyi } \\
\text { olması memnuniyeti } \\
\text { artırmaktadır. }\end{array}$ \\
\hline
\end{tabular}

Yapılan araştırmada, göl kenarında yöre halkı tarafından konteynır ve çadırlarda çay ve tost gibi ürünler satan turistik işletmeler Valilik tarafından kaldırtıldığı; bunun yerine, Yeşilova İlçe Kaymakamlığı'na bağlı olarak, göl kenarında ahşap yapılı işletme tesisleri oluşturulduğu belirlenmiştir. Salda Gölü Millet Bahçesi Projesi'ndeki işletmeler göl kenarına inşa edilene kadar bu ahşap yapılı işletmelerden hizmet verilmeye devam edileceği belirlenmiştir (Fig. 7, 8). Kafe ve büfe işletmelerinin Kaymakamlık tekelinde olması, yerel halkın sadece yöresel pazar ürünleri satarak turizmden yararlanması, yerel halkın turizmin alandaki gelişimine daha negatif bakmasina neden olmaktadır.

...Köylü Salda'ya gelen ziyaretçilerden memnun. Geçen yıl 20-30 tane köyün (konteynır) işletmeleri vardı. Kaymakamlık Valilik bunları yıktırdl, jandarma zoruyla kaldırttırdl. Kaymakamlık kendisi yaptırdı. Bu şekilde (ahşaptan) daha hoş olduğunu söylediler. Bize böyle bi Pazar yeri yaptılar. Ama bizim gözleme ve çaydan kazandiğımız daha yüksekti. Restorandan kazancımız daha yüksekti (K2).

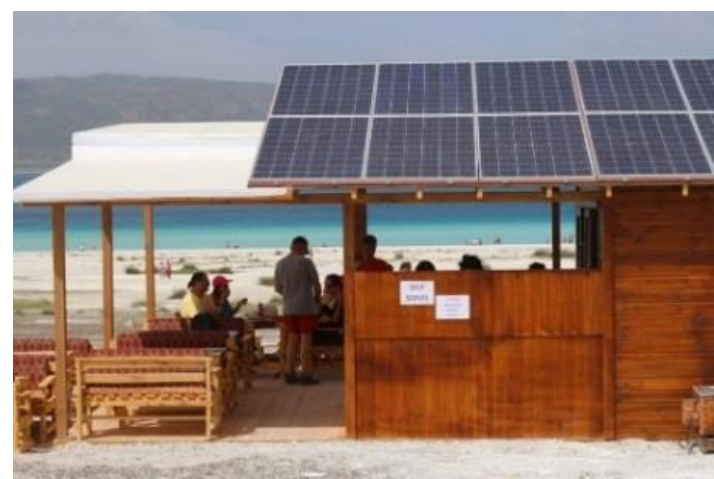

Fig. 7. Kaymakamlık tarafından işletilen işletmeler

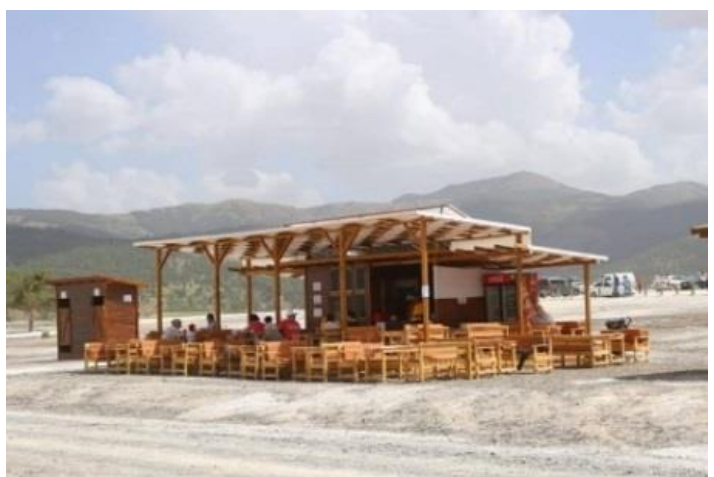

Fig. 8. Kaymakamlık tarafından işletilen işletmeler

Önceki yıllarda konteynır ve çadırlardan çay ve gözleme gibi yiyecek ve içecekler ziyaretçilerin yanına kadar götürülüp servis edildiği, ancak Kaymakamlık işletmelerinin self-servis olarak hizmet vermesinden dolayı ziyaretçilerde memnuniyetsizlik oluştuğu belirtilmektedir:

...Köylü herkesin ayağına gidiyordu, şimdi self-servis olduğu için millet kızıyor. Gelen şimdi kendisi alıyor çayını. Ama müşteri ayağına istiyor hizmeti. (eskiden) masasina gidiyordun, sohbet ediyordun. Önceden buraya gelenler "her şey ayağımıza geliyordu, eskiden böyle bir şey yoktu, buraya oturuyorum çay için, diğerine gidiyorum gözleme için, bu 
ney yav" diyor. Önceden çayını kahvesini ayă̆ına götürüyorduk. Daha hoşlarına gidiyordu. Şimdi büfeye gidiyor, oradan fiş kestiriyor, bize fiş̧i verip gidiyor, gözleme için 10-15 dakika sonra tekrar geliyor bize. Çayın ayrl yerden alıyor, gözlemesini ayrı yerden alyyor (K6).

Kaymakamlığa bağlı olarak işletilen bu tesislerde yöre kadın ve erkekleri İŞKUR üzerinden sezonluk olarak istihdam edilmiştir. Alanda altı ay gibi kısa bir süreliğine çalıştırılan bu kadınlar, yılın geri kalanında sigortasız ve işsiz olarak köylerinde yaşamlarına devam etmektedirler. Ancak kısa süreli de olsa bir gelir elde edilmiş ve sağlık sigortası gibi sosyal bir güvencenin sağlanmış olması bir kazanım olarak görülmekte ve bu işletmelere karşı olumlu bir tutum sergilendiği anlaşılmaktadır (Tablo 3):

Burayı hep Kaymakamlık aldı abam, o bakiyor. Kaymakamlık baklyor şimdi (göl işletmesine), Salda köyünün bu göl. Geliri Kaymakamlık alıyor, kafeteryaları Kaymakamlı çalıştırlyor (K1). Birazımız Yeşilova'dan, birazımız Salda köyünden. Bakkal, cafeleri, gözleme yerini işletiyoruz. Asgari ücret allyoruz, sigortamız yatıyor. O şekilde çalışıyoruz. ...Biz iki kişiyiz, gözleme yaplyoruz. Büfeye biri bakıyor. Cafe'de 3-4 kişi çalışlyor. Herkesin ayr ayrı bir işi oluyor ablam. ...Daha bu sene başladı bu işletmeler. ... Böyle olması da iyi, sigortamız oluyor (K2). Biz Kaymakamlık çalışanıyız. IŞ̧KUR çalı̧̧aniyız. Çöp topluyoruz, temizlik yapıyoruz. 13 kişiyiz böyle çalışan. Gözleme satan 4 kişi kaldık. Salda köyündeniz. Çok memnunuz, iyiki Kaymakamlık burayı aldı. İ̧s sahibi olduk. Pazarcılar şahısa aitti, şahıs kendi yapıyordu (işletiyordu). ...Köyümüzün bütün gençleri işsiz, bütün gençlerimiz çalıştı bak bu yıl. Çocuklarımızı okutuyoruz bi katkı oluyor. Oğlum lisede, kızım üniversitede, iki tane torun var. Altı ay sigortamız yatt. Bu devirde çok zor sigortasız. .... IŞKUR'da 9 bayan var. Tabi kendi işletenler istemiyorlar, böyle şeyi. Ama böyle bir sürü kişi ekmek sahibi oldu. Böyle daha iyi oldu (K6). Kendimiz (çay, tost) satsak çok gelir elde ederiz, ama onu hepimiz yapamıyoruz işte. Köylümüz konteynırlarda çeşitli yiyecekler, gözleme satarak Denizli'den bir daire parası kazandılar, bir yazda. ...Ama onu imkânı olan açabiliyor, imkânı olmayan açamıyor. Yine zengin açıyor, anladını mi? Ama böyle (olunca) fakirler faydalandı. Köylü yevmiye veriyor (yanında çalıştın mi), böyle asgari ücret sigortamı veriyor (IŞKUR). ...İyi $k i$ de Kaymakamlık aldı (K7).

Salda Köyü kadınlarının yöresel ürünleri göl kenarında oluşturulan pazar alanında satması, kırsal kalkınmanın sağlanması ve kırsal yoksulluğun azaltılması bakımından önemlidir. Ancak kadınların kendi işletmeleri yerine, Yeşilova Kaymakamlığ sezonluk olarak çalışması, kadın emeğinin taşeronlaşmasına ve emeğin sezonluk olarak düşük ücretle sömürülmesine neden olmaktadır.

Tablo 3. Alandaki İŞKUR İstihdamına İlişkin Tematik Kodlama

\begin{tabular}{llcl}
\hline Kategori & İfade (Açık Kodlama) & Aksiyel Kod & \multicolumn{1}{c}{ Seçici Kod } \\
\hline & Kadınlar olarak çalışıyoruz & Kadın & Kaymakamlık işletmelerinin \\
İŞKUR & $\begin{array}{l}\text { Böyle olması da iyi, sigortamız oluyor } \\
\text { İstihdamı }\end{array}$ & $\begin{array}{c}\text { Kaymakamlı sistem iyi oldu } \\
\text { kişi ekmek sahibi oldu }\end{array}$ & $\begin{array}{l}\text { kadıora sosyal güvence } \\
\text { sağlaması ve istihdam } \\
\text { oluşturması alandaki } \\
\text { memnuniyeti artırmaktadır. }\end{array}$ \\
\hline
\end{tabular}




\section{Kategori 3: Alandaki Faaliyetleri Kısıtlanan Diğer İşletmeciler}

Salda Gölü Belediye Halk Plajı kenarında Yeşilova Belediyesi’nin ve göl kenarında yer alan Kayadibi köyünden insanların işletmecilik yaptıkları görülmektedir (Fig. 9, 10). Belediye restoran-cafe işletme tesisinde soğuk ve sıcak içecekler, sabah kahvaltısı ve sicak yemek hizmeti sunulmaktadır. Bu işletmenin olması, karavan ve çadırda kalan ziyaretçilere ve günübirlik olarak alana gelen kişilere önemli bir hizmet sunmaktadır. Ancak alanın Özel Çevre Koruma (ÖÇK) Bölgesi içerisinde olmasından ve alana Salda Gölü Millet Bahçesi yapılacağından dolayı bu işletmelerin 2019 sezonu sonrasında hizmet vermeyeceği belirlenmiştir.

Keşke ziyaretçi sayısı artmasaydl, gelmeseydiler, sosyal medyada parlamasaydı göl. Gölü elimizden çıkardık. Bazı şeylerin reklam olması iyidir. Biz şimdi onun zararını görüyoruz şu anda. Orada bizim 27 yıldır işletmemiz vardl, geldiler millet bahçesi yapacă̆ız diye kaldırttılar. Öyle olmasaydl, ben oradan bu sene 6 ayda 2.350 bin lira para girdi belediyeye. Belediyenin kaynağı kurudu bitti (K12).

Yöre halkının gözleme, çay, ayran mısır gibi ürünler satmasına Yeşilova Kaymakamlığı'nın izin vermemesi, yöre halkı tarafından eleștirilmektedir. Yöre halkının bu tür satışları yapmasına izin verilmemesi, kırsal kalkınma ve turizmin sürdürülebilirliği bakımından negatif bir durum olarak görülmektedir (Tablo 4):

...Gözleme yapılacak gözleme yapmalarına izin vermediler. Ya insan gözleme neden yapmasin ki. Ben günlük 100 lira para neden kazanmayayım ya. Gelen vatandaş da memnun zaten. Yok, yiyecek yer yok gözleme. Ateş üzerinde ne güzel görüyorlar, gözünün önünde hamur açıyorlar. Hiçbir yerde izin vermiyorlar. Ne köfte yapabiliyorsun, ne kokoreç. Aklına gelen hiçbir şeyi yapamıyorsun. Mısır bile sattırmadılar ya. Misır bile sattırmadilar, çok ayıp ya. ...Polis hep var burada, 7/24, Yunuslar da dâhil. Kumsalda çadır kurulmasın, satıcılar olmasın. Onları denetliyorlar. İyi de vatandaş ne yapacak (K9). Köyün konteynır işletmeleri vardl, geçen yıl kaldirdılar. Şu gördüğünüz işletmeler Kaymakamlık'a ait. ...Bizim kafemiz vardı. adamlar geldi, bizim kafemizi köyün içinden kaldırtt, konteynır tarzında bir işletmemiz vardı orada. Neymiş, konteynırın yapı işletme ruhsatı olması gerekiyormuş. Biz de ruhsat için başvurumuzu yaptık. Köylüye normalde teşvik olması gerekirken, işletmeler için. Yani insanlara destek atması lazım. ...Ama köylüyü çıkardılar buradan, kendileri koydular, kendileri yapınca yasak yok, sit alanı yok. Biz yapınca ta imarlı arsadan kaldırdılar bizi. Şimdi sen köyümüzün turizminin kalkınmasını nasıl beklersin. O yasak, bu yasak, şu yasak. Bir şeyler yapmak istiyorsun o da yasak. Bu köy turizmle kalkinır mı hocam?... (K4). Herkesin arazisindeki konteynırları hep kaldırttı devlet. Gölün kenarında satış yapan çoktu. Sit alanı diyorlar, sit alanı neyse. Bina yaptırmıyorlar, çivi bile çaktırmıyorlar. Bir konteynır koyup da sergi açıp da orada alışveriş yaptırmıyorlar, devlet kendisi yapıyor. Adam kendi tapulu arsasina bir şey yapamiyor, yasak. Adamin gölün kenarında tapulu arazisinde (kontaynır işletmesinde) onu bile çalıştırmadılar yav. Ayıp, yemin olsun ayıp. "Ben devletim” diyor Kaymakamlık. Sen kiminle uğraşacaksın (K11). 


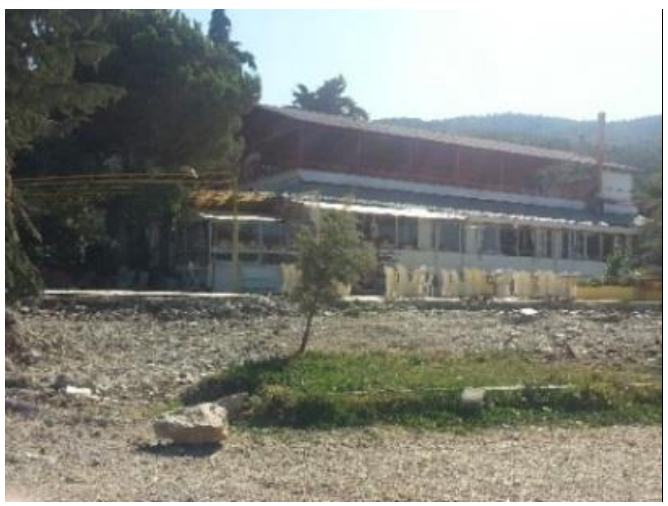

Fig. 9. Göl kenarında Belediye işletmesi

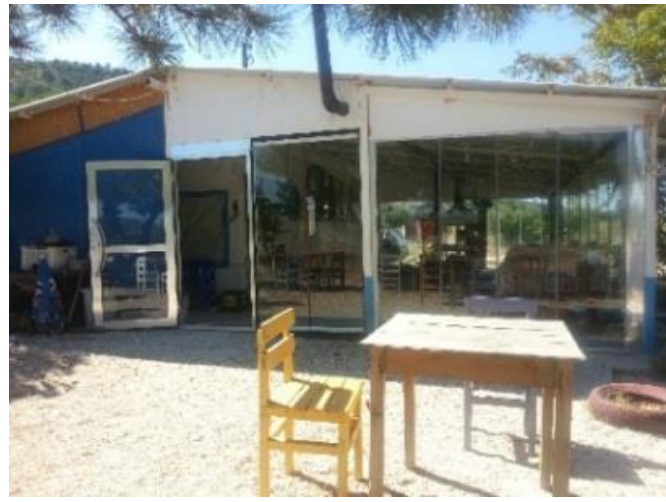

Fig. 10. Göl kenarında şahıs işletmesi (Ceylan)

Tablo 4. Turizmde İşletmelerinde Tekelciliğe İlişkin Tematik Kodlama

\begin{tabular}{|c|c|c|c|}
\hline Kategori & İfade (Açık Kodlama) & Aksiyel Kod & Seçici Kod \\
\hline $\begin{array}{l}\text { İşletmede } \\
\text { Tekelcilik }\end{array}$ & $\begin{array}{l}\text { Köylüyü çıkardılar buradan, kendileri koydular } \\
\text { (işletmeleri) } \\
\text { Kendileri yapınca yasak yok, sit alanı yok, bize } \\
\text { yasak } \\
\text { Köylü turizmin içinde olmak istiyor } \\
\text { Köylü kendisi çalıştırmak istiyor, ama veren yok } \\
\text { O yasak, bu yasak, şu yasak } \\
\text { Ben devletim” diyor Kaymakamlık }\end{array}$ & $\begin{array}{c}\text { İşletmek istiyoruz } \\
\text { Halka yasak } \\
\text { Devlete serbest }\end{array}$ & $\begin{array}{l}\text { Halkın işletmesi yasak, } \\
\text { devletin işletmesi serbest } \\
\text { anlayışı yerel halkta } \\
\text { tepkiye } \\
\text { olmaktadır. }\end{array}$ \\
\hline
\end{tabular}

\section{Kategori 4: Alanda Konaklama Durumu ve Günübirlik Turlar}

Araştırma alanına yılda yaklaşık 700 bin ziyaretçi gelmesine rağmen, alandaki konaklama arzı gelen bu ziyaretçilere cevap verebilecek sayıda henüz değildir. Turistik bir çekicilik olarak Salda Gölü, son 3 yılda popüler olması karşısında konaklama işletmeciliği alanda yeterli bir gelişim gösterememiştir. Bu nedenle, gelen ziyaretçiler genellikle günübirlik olarak alana gelmektedir.

Şu an yavaşladı. Ama yazın inanılmaz kalabalık. İşlerimiz şu an çok iyi değil. Günübirlikçiler geliyor çünkü. Pek fazla kalan olmuyor. Çünkü yatak yok, kalacak yer yok. ...Salda gölünün çevre köylere ekonomik anlamda şu an bir katkısı yok. Günübirlik gelip gidiyorlar. Çünkü haklilar vatandaşlar. Şu an ben gelsem ben de kalmam burda. Sosyal faaliyet geçirebileceğim bir yer yok (K9).

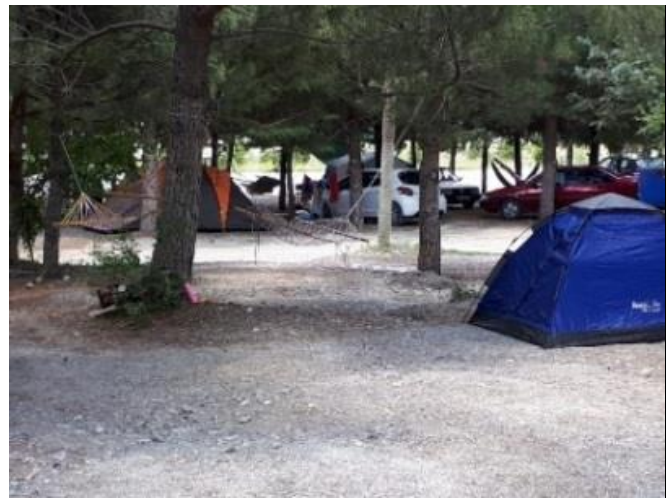

Fig. 11. Göl kenarındaki kamp alanları

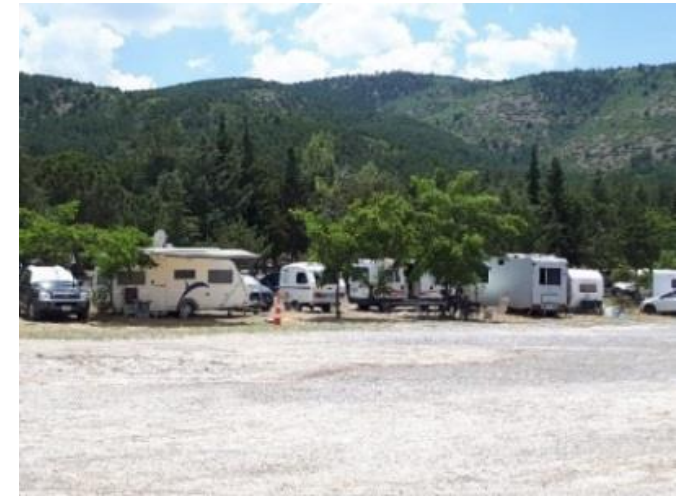

Fig. 12. Göl kenarındaki karavan alanları (Ceylan) 
Salda Gölü kenarında bazı yerli ve yabancı ziyaretçilerin kendi karavan ve çadırlarında konakladıkları ve rekreasyonel amaçlı göl alanından yararlandıkları görülmektedir (Fig. 11, 12). Salda Gölü Belediye Halk Plajı kenarında yer alan yaklaşık 15 bungalov (ahşap) ev ile gelen ziyaretçilere konaklama hizmeti sunulmaktadır. Bu evlerin içerisinde çift ve tek kişilik yatak ve duşakabinler bulunmakta olup, gecelik 100 Türk Lirası karşılığında Yeşilova Belediyesi tarafından konaklama hizmeti sunulmaktadır (Fig. 13-14).

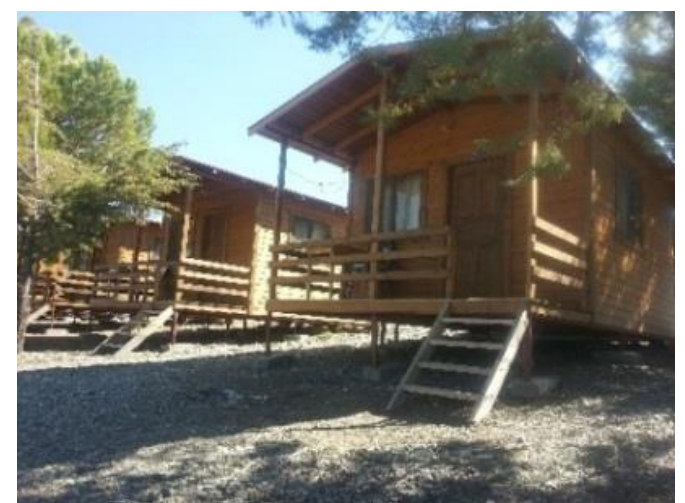

Fig. 13. Göl kenarındaki bungalov evler

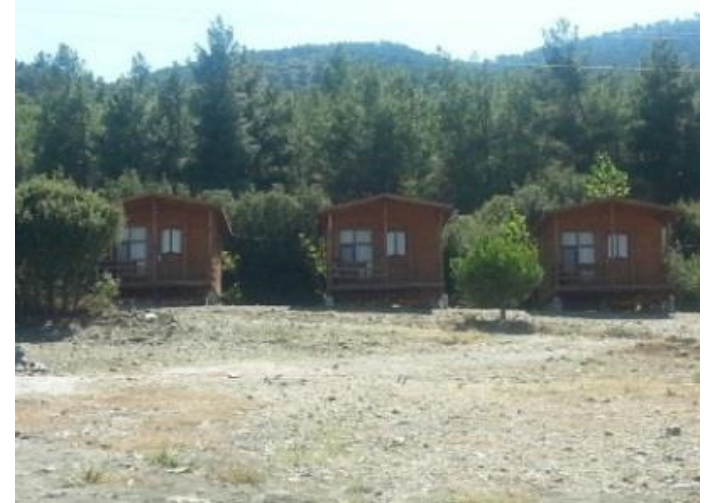

Fig. 14. Göl kenarındaki bungalov evler (Ceylan)

Salda Köyü içerisinde apart ve pansiyon tarzı işletmeler bulunmaktadır. Köyde yaklaşık 200 yatak kapasitesine ulaşan bu işletmelerin bir kısmının, ÖÇK Bölgesi içerisinde kalmasından dolayı, henüz işletme ruhsatı alamadığı görülmektedir:

Köyde pansiyon az veya çok var. Ama şimdi biz bunların kaçı ruhsatlı kaçı ruhsatsız bilmediğimiz için sana bir rakam veremeyiz. 3 tanesi ruhsatl olur, 5 tanesi kaçak olur, biz bir yerde ihbar etmiş gibi oluruz. ... Köyde apart var, apart sayısını vermeyelim, ama bana kaç yatak var dersen, ortalama ruhsatl 100 yatak var derim köyde. Ruhsatsızlarla 250 yatak da olabilir. Yeterli mi değil. ÖÇK olduğu için bunlar da şimdi ruhsat alamıyorlar. Hiçbir şey yapamıyorlar, bekliyorlar (K10). ...Şimdi köylü pansiyonculuk yapmak istiyorlar mesela. Ama inşaat yasak olduğu için başlayamıyorlar... (K9). Köyümüzde pansiyon çok, köyümüzün içi hep pansiyon. Çok apart var. Yeri müsait olan yaptyor. Yaz boyunca apartlar pansiyonlar hiç boş kalmadı. Daha hatta boş yer bulamadılar (K7). Köyün içerisinde pansiyonculuk çok. Köylü seviniyor. Mesela ben yen sene yaptıracağım, benim koca bahçem var. Pansiyon yaptıracağım. Ev yaparım 2-3 ailelik. Niye yapmayım ben (K1). Salda Köyü turizmden bir numara yararlaniyor şimdi. Bizim köyde 5-6 kişi evine apart cinsinden bir şey yaptı. Diğerleri de yararlanacak, bir şey yapayım diyorlar. Arazisine konteynır dahi koydurmuyorlar, kaldirtıyorlar (K8).

\section{Kategori 5: Salda Gölü Millet Bahçesi Projesi}

Yerel halk, Salda Gölü çevresine yapılacak olan Millet Bahçesi'ni desteklediği, ancak proje ihalesi hakkında kendileri ile detayların paylaşılmadığı ve kendilerine bir bilgi verilmediği gerekçesiyle süreci eleştirdikleri görülmektedir (Tablo 5):

Şimdi Millet Bahçesi yapılacak diyorlar. Milet bahçesi nedir, ne yapacaklar, nereye yapılacak hiçbir kimsenin bir bilgisi yok. Bir şey de demiyorlar şuraya şu yapılacak buraya bu yapılacak. Milletin korkusu: 
Saldagölünü elimizden alacaklar, yarın imara açacaklar, Türkiye'nin zenginlerine verecekler, bizi katmayacaklar...(K8). Burasina zaten gelecek sene bir şey yaptırmazlar zaten. Millet bahçesi mahkemelik şimdi, o bitti mi buraya başlarlar inşaata. Köylü karşı çıkıyor tabi bu duruma. Köylünün bir şeysi yok ki burada. Millet bahçesine ve hepsine karşı. Buraya gelip gitmelerine bile karşı. Köylü sokulmuyor ki buraya. Köylü turizmin içinde olmak istiyor, kendisi çalıştırmak istiyor, ama veren yok (K4).

Salda Gölü Millet Bahçesi'nin işletme ihalesine yerel halkın dâhil edilmediği ve kendilerinin sürecin dışında tutulduğu belirtilmektedir. Yerel halk olarak turizmin içinde olmak istedikleri, ancak dışardan gelenlere ihaleleri verecekleri yönündeki kaygıların yükseldiği belirlenmiştir. Kırsal kalkınma ve yerel ekonomik gelişme için ihalelere yerel halkın dâhil edilmesi ve kendileri bu konuda teşvik edilmeleri gerektiği ifade edilmektedir.

Millet bahçesi ihalesine çıkıldl, gölü kimin işleteceği belli, ama biz bilmiyoruz onu. Salda gölünü mahkemeye verdiler, millet bahçesi yapıminı durdurdular. Mahkeme sonuçlanacak. Valla şimdi biz ona (mahkeme sonucuna) baklyoruz şimdi. Bize bir bilgilendirme yapmiyorlar... (K8). Muhtemelen buraya yapllacak olan projelerde köylüyü barındırmak istemiyorlar. Çünkü köylüye verirse, elin zengini alamayacak köylünün elinden. ...parası olan basacak ihaleyi alacak. ... Elin zengini geldi mi, köylü ne yapabilir ki abim. Benim çıkarabileceğim para ne ki (K4). ...Millet bahçesinin yapılması buranın halkı için çok iyi olur. Tek kötü tarafi nedir? Belki bu yöre halkını işin içine katmazlar. Millet bahçesi yapıldı ğında buranın kullanım hakkı kimde olacak bilmiyoruz. Hükümet nasıl yapacak. Devletin elinde. ....Millet bahçesine yapılacak işletmelerin ihalesine köylünün girme şansı yok. Köylünün (ihaleyi) alma şansı yok ki. Cebinde elli bin lirası vardır ama aylık 3 bin lira (kira) dan 36 bin lira yapıyor yıllık. Ben oraya bir de eleman alacağım, malzeme alacağım, neyle alacağım ben onu. Ama deseler ki ihale şartnamesine, yerli halka yüzde yetmiş avantaj. O zaman yerli halkta kalır burasi, yerli halk da zorlar kendini biraz. Aksi takdirde yerli halksn buradan ihale alma şansı yok (K11). Doğanbaba köy halkı da olsun istiyorlar millet bahçesini. Ama doğa bozulmasın ama bizim yerel halka biraksınlar işletmesini. Onlar da öyle istiyorlar. Ben İstanbul'da müttehittim (mesela), kendi yeğenimi dayımı getirdim koydum buraya, o para burada kalmayacak ki. Bana bir faydast olmayacak ki onun. Hiçbir faydası yok ki bana. Neden gelsin ki o adam buraya (K5). Merkezi hükümet, gölle ilgili bize hiçbir şey sormadan millet bahçesi projesi hazırlyyor. ....Millet bahçesi müteahhite verilmiş. Alan müteahhitler geldi, benimle tanıştılar. Malatyalı. Biz dedi burayı aldık. Bir aya kadar şantiyemizi kuracağız dedi (K12).

Salda Gölü Millet Bahçesi Projesi'nde yöre halkının sürecin içerisine dâhil edilmemesi kırsal ekonomik gelişme ve yoksulluğun azaltılması bakımından negatif bir durumdur. Millet Bahçesi projesi işletmelerinin dışardan gelen sermaye sahiplerine verilmesi, yerel halkın işletmeci pozisyonundan çıkıp sezonluk olarak düşük ücretle çalışmasının önünü açabilecektir. 
Tablo 5. Millet Bahçesi Projesi’ne İlişkin Tematik Kodlama

\begin{tabular}{|c|c|c|c|}
\hline Kategori & İfade (Açık Kodlama) & Aksiyel Kod & Seçici Kod \\
\hline \multirow{5}{*}{$\begin{array}{l}\text { Millet } \\
\text { Bahçesi }\end{array}$} & Köylünün (ihaleyi) alma şansı yok ki & & Millet bahçesi ihalesine \\
\hline & Yapılacak olan projelerde köylüyü barındırmak & & köylünün dâhil \\
\hline & istemiyorlar & $\begin{array}{c}\text { Proje } \\
V\end{array}$ & edilmemesi ve \\
\hline & Salda Gölünü elimizden alacaklar & $\begin{array}{l}\text { Koylu } \\
\text { Rizi katmigrlar }\end{array}$ & kendilerine bilgi \\
\hline & $\begin{array}{l}\text { Milet bahçesi nereye yapılacak hiçbir kimsenin } \\
\text { bir bilgisi yok }\end{array}$ & $\begin{array}{l}\text { Bilz katmilyorrar } \\
\text { Bilgi verilmiyorlar }\end{array}$ & $\begin{array}{l}\text { verilmemesi tepkiye } \\
\text { neden olmaktadır. }\end{array}$ \\
\hline
\end{tabular}

Araştırma alanında yapılan gözleme ilişkin bulgular genel olarak değerlendirildiğinde:

Turizmin alandaki ilk gelişimi el yordamı ile gittiği, ancak 2019 yılı içerisinde yerel yönetimlerce çevre düzenlemesi yapıldığg görülmektedir. Gölün beyaz kumsalına özel araçlar ile girilmemesi için ahşap kazıklar ile bariyer oluşturulmuştur. Alanın ekolojik hassasiyeti nedeniyle ÖÇK kapsamında korumaya alındığını ve bu nedenle suda derinleştirilmemesi, sahil kilinin (kumunun) alınmaması, sahilde ateş yakılmaması ve kamp çadırı kurulmaması için gerekli ahşap uyarı levhalarının asıldığı görülmektedir. Ayrıca çöp kutuları, geri kazanım için atık toplama kutucuklarının yerleştirilmiş olduğu ve sahil kenarında resmi polis aracı ile ekiplerin dolaştığı görülmektedir. Plaj girişlerindeki toprak zeminde otopark alanlarının oluşturulmuş olması, plajlara ziyaretçi giriş ücretlerinin alınması alandaki diğer düzenlemeler olarak gözlemlenmiştir. Salda köyü plajı girişinde yer alan yöresel ürün pazar alanında gelen ziyaretçiler ile yöre halkının ilk buluşma (temas) alanı olduğu; bu iki grubun burada alışveriş için iletişim kurduğu görülmektedir. Yerel halktan kadın ve erkeklerin ahşap yapılı işletmelerde (gözleme, büfe, kafe) çalıştığı gözlemlenmiştir. Yöre insanlarının samimi, içten ve güler yüzlü bir şekilde iletişim kurdukları görülmektedir. Belediye halk plajında çadır ve karavanlarla kamp yapan bireyler ve aile grupları görülmüş, Almanya plakalı bir karavan ile yabancı ziyaretçilerin kamp alanında olması dikkat çekmiştir. Belediye plajı kenarında piknik için ahşap masaların ve çocuk oyun parkının oluşturulduğu gözlemlenmiştir. Ayrıca belediye işletmesi olan bir restoran işletmesinin de göl kenarında olması dikkat çekmektedir. Salda Gölü Tabiat Parkı ise, ziyaretçi tanıtım merkezi, kır lokantası, çocuk parkı, wc ve soyunma kabini üniteleri ile göl kenarında gelen ziyaretçilere ayrı bir rekreasyon hizmeti sunduğu görülmektedir.. Ancak ziyaretçi yoğunluğunun genellikle Salda köyü plajı ve belediye plajında olduğu gözlemlenmektedir. Alana gelen ziyaretçilerin büyük bir kısmının özel araçları ile geldiği, ancak buna karşın PEGAS, $A N E X$ gibi özel tur otobüslerinin alana tur düzenlediği gözlemlenmiştir. Ziyaretçilerin fotoğraf çekmesi yoğun olarak görülürken, ziyaretçilerin bir kısmı deniz mayo kıyafetleri ve havluları ile geldikleri ve gölde yüzdükleri, sahilde güneşlendikleri ve plaj şemsiyesi altında gölgelendikleri; diğer bir kısım insanların ise pantolon ve elbiselerini yukarı katlayarak ayaklarını sı ̆ suya soktukları ve göl kenarında yürüdükleri görülmektedir. Göle gelen ziyaretçilerin sahil gerisinde yer alan wc, duş alma alanları ve ahşap soyunma kabinlerini kullandıkları, Kaymakamlık işletmeleri olan ahşap yapılı büfe ve gözleme kabinlerinden alış veriş yaptıkları, kafe önünde oturarak bu mekânları etkin bir şekilde kullandıkları görülmektedir. Ziyaretçilerin fotoğraf çekimi sırasında, göl kenarında ve su içerisinde yürürken tebessüm etmeleri, gülmeleri alandaki deneyiminin pozitif yönde olduğunu ve bir doyum sağladıklarını göstermektedir. Sonuç olarak, alandaki koruma ve denetimlerin artırıldığ 1 , bilinçlendirme levhaları ve çevre düzenlemelerinin k1smen sağlandığı görülmektedir.

\section{Sonuç}

$\mathrm{Bu}$ çalışma, kırsal alanda turizmin gelişimini ve yerel halkın bu konudaki tutumunu belirlemek ve yerel halkın turizmden ekonomik olarak nasıl yararlandığını ortaya koymak için yapılmıştır. Yerel halkın turizmle ilgili tutumu, literatürle tartışlan SDT ve turizmin ekonomik etkileri ile 
ilişkilendirilmiştir. Araştırmada, yerel halkın alandaki turizm faaliyetlerinden ekonomik olarak bir fayda sağladığı belirlenmiştir. Yöresel turistik ürünlerin alana gelen ziyaretçilere satılması, kırsaldaki kadınların sezonluk da olsa istihdam edilme imkânı bulması, Salda Köyü içerisindeki yaptırılan pansiyon ve apart otellerde konaklama hizmeti sunulması yerel halkın turizmden elde ettiği faydalar olarak sıralanabilir. Göl çevresinde yaşayan yerel halk, turizmden sağladığ 1 ekonomik fayda nedeniyle, turizmin gelişimine ve alana gelen ziyaretçilere karş1 olumlu bir düşünceye sahip olduğu tespit edilmiştir. Başka bir ifadeyle, yöresel ev yapımı ürünlerin göl kenarında turistik bir ürün olarak satışa sunulması ve bu ürünlerden yerel halkın ekonomik olarak bir gelir elde etmesi, ev sahibi toplumun turizmin alandaki gelişimine olumlu bakmasına imkân sağlamaktadır. Ayrıca kadınların sezonluk da olsa, göl kenarındaki Kaymakamlık işletmelerinde istihdam edilmesi ve sosyal bir güvenceye kavuşması, kırsal ekonomik gelişme için önemli bir faktördür. Ancak alanın 2019 yılında ÖÇK bölgesi ilan edilmesinden dolayı, yerel halkın çadır ve konteynır işletmelerinde (gözleme, ayran, çay vb.) satış yapmasına izin verilmemesi, köy içerisinde apart otel, pansiyon yapmada ve işletme ruhsatı almada ÖÇK nedeniyle yasal izinlerin verilmemesi yerel halkın alandaki turizmin gelişimine karşı eleştirel olmasına neden olmuştur. Alanda görülen bu durum, Ekici \& Çizel'in $(2014,84)$ “yerel halk, turizmin gelişiminden fayda sağladıkça turizmin pozitif etkileri konusunda algı seviyelerinin arttığ" sonucu ile örtüşmektedir. Diğer bir deyişle, SDT'deki "faydacılık" düzeyindeki artış, turizme ve turizmin alandaki gelişimine karşı yerel halkın olumlu bir algıda olmasına neden olmaktadır. Bu durumda ise, çalışmanın bulguları SDT ile örtüşmekte ve SDT ile yapılan diğer araştırmalar (Perdue et al. 1987; Yoon et al. 2001; Teye et al. 2002; Harrill 2004; Lee 2013; Ekici \& Çizel 2014) ile benzer sonuçlar göstermektedir.

Salda Gölü çevresinde gelişen turizm faaliyetleri ile sınırlı sayıda da olsa bir istihdamın oluşturulması ve işsizlik sorununa olumlu bir katkı sağlanması, kırsal ekonomik gelişme için önemlidir. Ancak yerel yönetimlerin turizm işletmelerinde bir tekel oluşturması ve yerel halkın işletme yeri açmasına izin vermemesi halkın bu durumu eleştirmesine ve negatif bir tutum göstermesine neden olmaktadır. Kırsal yoksulluğun azaltılmasında yerel halkın turizmin içinde olmasına daha fazla önem verilmeli, hazırlanmakta olan alan yönetim planı içerisinde de bu konu etraflıca ele alınmalıdır.

Yerel yönetimlerin alandaki koruma ve denetleme uygulamaları, yerel halkın turizm huşusundaki tutumunu negatife çevirmektedir. Göl kenarında ÖÇK nedeniyle sıkı bir koruma ve denetleme faaliyetinin gerçekleştirilmesi, yerel halkın gözleme, tost ve içecek satmasına izin verilmemesine neden olmaktadır. Diğer bir deyişle, yerel halkın önceki yıllarda gözleme, tost ve içeceklerle hizmet verdiği seyyar konteynır ve çadırların Kaymakamlık tarafından kaldırtılması, Kaymakamlığın aynı yerde kendisinin bu hizmeti verecek işletmeleri açması, yerel halkın bu durumu eleştirmesine neden olmaktadır. Nitel temalarda bu durum, "halkin işletmesi yasak, devletin işletmesi serbest" şeklinde ortaya çıkmaktadır. Yerel halkın göl kenarında seyyar olarak da olsa işletme açmasına izin verilmemesi, kendilerini dışlanmış ve ayrıştırılmış hissetmelerine neden olabilecektir. Dışlanma ve ayrışmanın oluşması, ileriki dönemlerde sosyal çatışmayı da beraberinde getirebilecektir. Bu nedenle, göl havza alanının korunmasının gerekliliği ve bu konuda yapılan uygulamaların amacı, yerel halka anlatılmalı ve yöre insanı bu konuda bilinçlendirilmelidir. Ayrıca yöre insanını dışlayıcı kararlar yerine, yerel halkın turizm işletmeleri içerisine ve planlamaya dâhil edilmesi gerekmektedir.

Salda Gölü kenarına yapılacak olan Millet Bahçesi İşletme İhalesi'nin dışardan gelen kişilere verilmesi ve yerel halkın yöresel ürünlerin satışı dışında turizmin gerisinde tutulması durumunda, yerel halkı turizmin gelişimine karşı bakışı daha olumsuz olacaktır. $\mathrm{Bu}$ durum ise, turizmin alandaki sürdürülebilir gelişimini zora sokacaktır. Ayrıca yoksul kırsal kesimin sezonluk olarak alanda istihdam edilmesi, yerel ekonomik gelişme için önemli olsa da kadınların turizmde eğitilerek ve kadın kooperatifleri üzerinden örgütlenmesi sağlanarak turizm içerisinde daha aktif rol 
almaları ve kendi işletmelerini kurmaları sağlanmalıdır. Sonuç olarak, kırsal ekonomik gelişme için; yerel halkın gölün alan yönetim planı içerisine dâhil edilmesi, turizmin içerisinde olmasına özendirilmesi ve yönetimsel sıkıntılarının giderilmesinin sağlanması gerekmektedir. Başka bir deyişle, yöre insanlarının turizm kaynaklı sorunlarının belirlenmesi ve bu sorunların çözüme kavuşturulması ile alanda turizm sürdürülebilirliğini sağlayacaktır. Bu nedenle, kırsal kalkınma için, göl alanının çevresel, sosyal ve ekonomik gelişiminin bütüncül olarak değerlendirilmesi gerekmektedir.

\section{KAYNAKÇA}

Altunel M. C. (2009). Yerel Halkın Turizmin Gelişsimine Verdiği Desteği Etkileyen Faktörlerin Sosyal Değişim Teorisi Açısından İncelenmesi: Alaçatı Örneği. Yayımlanmamış Yüksek Lisans Tezi, Sakarya Üniversitesi, Sakarya 2009.

Ap J. (1992). "'Resident” Perception on Tourism Impacts”. Annals of Tourism Research 19/4 (1992) 669672. https://doi.org/10.1016/0160-7383(92)90060-3

Baykal F. (2004). "Yerel Ekonomi Ürünlerinin Kırsal Turizm İçin Önemi ve İzmir Örneği". II. Uluslararası Turizm, Çevre ve Kültür Sempozyumu Bildirileri (10-11 Mayıs 2004). (2004) 113-125.

Chuang S. T. (2010). "Rural Tourism: Perspectives from Social Exchange Theory". Social Behaviour and Personality: An International Journal 38/10 (2010) 1313-1322.

co S. \& Querini G. (2003). "The Role of Tourism in Sustainable Economic Development". Presentation at the $43^{\text {rd }}$ Congress of the European Regional Science Association (27-30 August 2003), (2003) 117. https://www.econstor.eu/bitstream/10419/115956/1/ERSA2003_084.pdf

Çalışkan U. \& Tütüncü Ö. (2008). "Turizmin Yerel Halk Üzerindeki Etkileri ve Kuşadası İlçesi Uygulamaları”. IV. Lisansüstü Turizm Öğrencileri Araştırma Kongresi Bildirileri (23-27 Nisan 2008). (2008) 127-148.

Çeken H., Karadağ L. \& Dalgın T. (2007). "Kırsal Kalkınmada Yeni Bir Yaklaşım Kırsal Turizm ve Türkiye'ye Yönelik Teorik Bir Çalışma”. Artvin Çoruh Üniversitesi Orman Fakültesi Dergisi 8/1 (2007) 1-14. http://static.dergipark.org.tr/article-download/imported/1046000163/1046000172.pdf?

Dimitrios S., Avital B., Jason S. \& Szivas M. Eds. (2014). "Residents' Support for Tourism Development: The Role of Residents' Place Image and Perceived Tourism Impacts". Tourism Management 45 (2014) 260-274. https://doi.org/10.1016/j.tourman.2014.05.006

Durbarry R. (2002). "The Economic Contribution of Tourism in Mauritius". Annals of Tourism Research 29/3 (2002) 862-865. DOI: 10.1016/S0160-7383(02)00008-7

Ekici R. \& Çizel B. (2014). "Yerel Halkın Turizm Gelişimi Desteğine İlişkin Tutumlarının Destinasyonların Gelişme Düzeylerine Göre Farklılıkları". Seyahat ve Otel Işsletmeciliği Dergisi 11/3 (2014) 7387. http://static.dergipark.org.tr/article-download/imported/5000086060/5000080111.pdf?

Eralp Z. (1974) Socio-Economic Effects of Tourism towards Communal Changes. Ankara 1974.

García F. A., Balbuena V.A. \& Cortes M. R. (2015). "Resident's Attitudes towards the Impacts of Tourism". Tourism Management Perspectives 13 (2015) 33-40. https://doi.org/10.1016/ j.tmp.2014.11.002

Getz D. (1994). "Residents' Attitudes Towards Tourism: A Longitudinal Study in Spey Valley, Scotland". Tourism Management 15/4 (1994) 247-258. https://doi.org/10.1016/0261-5177(94)90041-8

Lindberg K. \& Johnson R. L. (1997). "Modeling Resident Attidutes Toward Tourism". Annals of Tourism Research 24/2 (1997) 402-424. https://doi.org/10.1016/S0160-7383(97)80009-6

Göktaş-Kulualp H. \& Sarı Ö. (2019). "Destekleme Davranışı ve Sosyal Değişim Teorisi Kapsamında Kırsal Turizmin Etkilerinin Değerlendirilmesi”. MANAS Sosyal Araştırmalar Dergisi 8/1 (2019) 643666. http://static.dergipark.org.tr/article-download/82a6/e06a/e0aa/5cb00f063c990.pdf?

Hanafiah M. H., Raziff J. M. \& Izzat Z. M. (2013). "Local Community Attitude and Support Towards Tourism Development in Tioman Island, Malaysia". Procedia - Social and Behavioural Sciences 105 (2013) 792-800. https://doi.org/10.1016/j.sbspro.2013.11.082

Harrill R. (2004). "Residents' Attitudes toward Tourism Development: A Literature Review with Implications for Tourism Planning”. CPL Bibliography 18/3 (2004) 251-266. http://citeseerx.ist.psu.edu/viewdoc/download?doi=10.1.1.477.4384\&rep=rep1\&type=pdf

Jurowski C., Uysal M. \& Williams R. D. (1997). "A Theoretical Analysis of Host Community Resident Reactions to Tourism". Journal of Travel Research 36/2 (1997) 3-11. https://doi.org/10.1177/ 
004728759703600202

Látková, P. \& Vogt, C.A. (2012). "Residents' Attitudes toward Existing and Future Tourism Development in Rural Communities". Journal of Travel Research 51/1 (2012) 50-67. https://doi.org/10.1177/0047287510394193

Lee T. H. (2013). "Influence Analysis of Community Resident Support for Sustainable Tourism Development". Tourism Management 34 (2013) 37-46. doi:10.1016/j.tourman.2012.03.007

Mason P. \& Cheyne J. (2000). "Residents' Attitudes to Proposed Tourism Development". Annals of Tourism Research 27/2 (2000) 391-409. https://doi.org/10.1016/S0160-7383(99)00084-5

Mathieson A. \& Wall G. (1992) Tourism, Economic, Physical and Social Impacts. Longman Specific and Technical, London 1992.

Meyer D. F. \& Meyer N. (2015). "The Role and Impact of Tourism on local Economic Development: A Comparative Study". African Journal for Physical, Health Education, Recreation and Dance 21/1:1 (2015) 197-214. https://journals.co.za/content/ajpherd/21/Issue-11/EJC172415

Modeste N. C. (1995). "The Impact of Growth in the Tourism Sector on Economic Development: The Experience of Selected Caribbean Countries". Economia Internationale 48 (1985) 375-385. https://econpapers.repec.org/article/risecoint/0394.htm

Oğuzbalaban G. (2017). “Türkiye'de Yerel Halkın Turizme ve Turizmin Etkilerine Yönelik Algı ve Tutumlarına İlişkin Yazın Taraması”. Uluslararası Sosyal Araştırmalar Dergisi 10/51 (2017) 1321-1329. http://www.sosyalarastirmalar.com/cilt10/sayi51_pdf/8diger_sosyalbilimler/oguzbalaban_oguz.pdf

Özdemir M., Gürkam M. İ. \& Kıral M. (2000). "Turizm Hareketlerinin Sosyo-Ekonomik Yapıya Etkisi: Belek, Karpas ve Girne Üzerine Karşılaştırmalı Bir İnceleme”. Anatolia: Turizm Araştırmaları Dergisi 11/2 (2000) 79-91.

Perdue R. R., Long P. T. \& Allen L. (1987). "Rural Resident Tourism Perceptions and Attitudes". Annals of Tourism Research 14/3 (1987) 420-429. https://doi.org/10.1016/0160-7383(87)90112-5

Richardson R. B. (2010). The Contribution of Tourism to Economic Growth and Food Security. USAID, Office of Economic Growth, Mali 2010.

Roberts L. \& Hall D. (2001). Rural Tourism and Recreation: Principles to Practice. Wallingford, UK: CABI 2001.

Steiner C. (2006). "Tourism, Poverty Reduction and the Political Economy: Egyptian Perspectives on Tourism's Economic Benefits in a Semi-Rentier State". Tourism Hospitality Planning and Development $3 / 3$ (2006) 161-177. https://doi.org/10.1080/14790530601132286

Terzioğlu M. \& Gökovalı U. (2017). "Turizmin Yerel Ekonomik Etkilerinin Belirlenmesi: Marmaris Otelcilik Endüstrisi Örneği”. Anatolia: Turizm Araştırmalarl Dergisi 28/1 (2017) 27-38. http://static.dergipark.org.tr/article-download/e252/3bac/c593/5927388dd7209.pdf?

Teye V., Sirakaya E. \& Sönmez S. F. (2002). "Residents' Attitudes toward Tourism Development". Annals of Tourism Research 29/3 (2002) 668-688. https://doi.org/10.1016/S0160-7383(01)00074-3

Torun E. (2013). "Kırsal Turizmin Bölge İnsanına Katkıları”. KMÜ Sosyal ve Ekonomik Araştırmalar Dergisi 15/24 (2013) 31-37. http://static.dergipark.org.tr/article-download/imported/5000134206/ 5000123021.pdf?

UNCTAD (2010). The Contribution of Tourism to Trade and Development. Trade and Development Board, Geneva 2010.

Ün E., Tutar F., Tutar E. \& Erkan Ç. (2012). "Ekonomik Kalkınmada Kırsal Turizmin Rolü: Türkiye Örneği”. International Conference on Eurasian Economies (2012) 345-350. https://www.avekon.org/ papers/486.pdf

Vaugeois N. (2000). "Tourism in Developing Countries: Refining a Useful Tool for Economic Development". (2014 September 10): Kaynak: http://fama2.us.es

Yoon Y., Gursoy D. \& Chen J. S. (2001). "Validating a Tourism Development Theory with Structural Equation Modelling”. Tourism Management 22/4 (2001) 363-372. DOI: 10.1016/S02615177(00)00062-5

\section{Internet Kaynakları}

BM Dünya Turizm Örgütü (2002). Tourism and Poverty Alleviation https://www.e-unwto.org/doi/book/10.18111/9789284405497 Erişim Tarihi: 05.07.2019

Burdur İl Kültür ve Turizm Müdürlüğü. "İstatiksel Veriler" https://burdur.ktb.gov.tr/TR-155327/istatistikler-ve-veriler.html adresinden Erişim Tarihi: 08.08.2019

Burdur Yeşilova. https://www.facebook.com/brdryesilova/photos/a.124338815590214/ 124339225590173/?type=3\&theater. Erişim Tarihi: 11.07 .2019 